\title{
On a new genus and species of Hemicytheridae (Ostracoda, Crustacea) from the southern Brazilian coast
}

\author{
Anderson L. M. de Morais \& João C. Coimbra
}

Universidade Federal do Rio Grande do Sul, Departamento de Paleontologia e Estratigrafia, Caixa Postal 15001, 91501-970, Porto Alegre, RS, Brazil. (crescermorais@hotmail.com; joao.coimbra@ufrgs.br)

\begin{abstract}
This study is based on 62 samples of phytal and bottom sediments collected along rocky beaches ( $\leq 3 \mathrm{~m}$ water depth) of the central and northern coasts of the state of Santa Catarina $\left(26^{\circ} 10^{\prime} / 27^{\circ} 50^{\prime} \mathrm{S}-48^{\circ} 26^{\prime} / 48^{\circ} 40^{\prime} \mathrm{W}\right)$, southern Brazil. Living and dead ostracodes distributed among 16 families were recovered. In this paper is emphasized one new hemicytherid genus and species that is described and richly illustrated: Auricythere sublitoralis gen. nov. and sp. nov. Some ecological and zoogeographical aspects of this new ostracode are briefly discussed.
\end{abstract}

KEYWORDS. Taxonomy, Aurilini, state of Santa Catarina, Atlantic Ocean.

RESUMO. Sobre um novo gênero e espécie de Hemicytheridae (Ostracoda, Crustacea) da costa sul-brasileira. Foram coletadas 62 amostras de sedimentos de fundo e fital no infralitoral rochoso superior $(\leq 3 \mathrm{~m}$ de profundidade) das regiões central e norte do Estado de Santa Catarina $\left(26^{\circ} 10^{\prime} / 27^{\circ} 50^{\prime} \mathrm{S}-48^{\circ} 26^{\prime} / 48^{\circ} 40^{\prime} \mathrm{W}\right)$. Os ostracodes vivos e mortos recuperados estão distribuídos em 16 famílias, destacando-se, neste trabalho, um novo gênero e espécie de Hemicytheridae ricamente descrito e ilustrado: Auricythere sublitoralis gen. nov., sp. nov. Alguns aspectos ecológicos e zoogeográficos deste novo táxon são brevemente discutidos.

PALAVRAS-CHAVE. Taxonomia, Aurilini, Estado de Santa Catarina, Oceano Atlântico.

The study of benthic marine ostracodes from Brazil began with BRADY (1880), in his monumental work on benthic ostracodes from different oceans, identified some species of ostracodes recovered, including from deep-waters of northeastern region of Brazil, all of them collected during the H.M.S. Challenger Expedition. HarTMAnN $(1955,1956)$ described some new species from samples collected by hand off Santos city and Bela Island, both places localized in the north coast of the state of São Paulo, southeastern Brazil. Later, Pinto et al. (1978), a landmark in the study of these microcrustaceans in this country examined hundreds of bottom sediment samples collected along 7,408 km of the continental shelf, identifying, preliminarily, about 50 genera of Ostracoda. Following them, Ramos (1996), Coimbra et al. (1999), Machado et al. (2005) and Bergue $\&$ Coimbra (2008) continued these studies where a more detailed bibliographic review is presented.

Most work on marine benthic ostracodes of Brazil has been devoted to the study of species recovered from the continental shelf, and more recently from the slope (Bergue \& Coimbra, 2008). Ostracodes from coastal regions are still poorly understood, highlighting herein the studies of Hartmann $(1955,1956)$, already cited above, and Ornellas (1974, Tramandaí town, state of Rio Grande do Sul), CormBra et al. (1992, Tamandaré Bay, state of Pernambuco), Dias-Brito et al. (1988, Sepetiba Bay, state of Rio de Janeiro), Coimbra \& Bergue (2003, São Sebastião town, state of São Paulo), CoImBra et al. (2007, Cananéia town, state of São Paulo, and references therein) and CoImBra \& Bergue (2011, northern coast of the state of São Paulo).

The main purpose of this study is the description of one new hemicytherid genus and species, Auricythere sublitoralis gen. nov., sp. nov., recovered living and dead from the upper rocky sublitoral ( $\leq 3 \mathrm{~m}$ water depth) of the central and northern coasts of the state of Santa Catarina $\left(26^{\circ} 10^{\prime} / 27^{\circ} 50^{\prime} \mathrm{S}-48^{\circ} 26^{\prime} / 48^{\circ} 40^{\prime} \mathrm{W}\right)$. The other species of ostracodes recorded in the study area, distributed in 16 families, are part of an ongoing project.

\section{MATERIAL AND METHODS}

This study was based on samples of phytal and bottom sediments collected along rocky beaches of eight municipalities of the state of Santa Catarina, between the coordinates $26^{\circ} 10^{\prime} / 27^{\circ} 50^{\prime} \mathrm{S}$ and $48^{\circ} 26^{\prime} / 48^{\circ} 40^{\prime} \mathrm{W}$ (Fig. 1; Tab. I). Most of the southern and southeastern coast of Brazil, including the sampled region, presents micro-tidal regime (amplitude $\leq 2 \mathrm{~m}$ ), and is inserted in the Southeast Coastal Region (Cabo Frio - Cabo de Santa Marta), formed mainly by sandy beaches with intermittent rocky spits (Coutinho, 2000; Tessler \& Goya, 2005). According to Pereira et al. (2009), the seawater average surface temperature ranges from $21^{\circ}$ to $24^{\circ} \mathrm{C}$ in the months of April and May, during which the fieldwork was conducted (see Hesp et al., 2009 for additional information on the study area).

The samples were collected handly, immediately after the low tidal mark, reaching up to $3 \mathrm{~m}$ of depth. Encrusting algae were scraped off and bagged, while arborescent algae had some branches involved in a plastic bag and then this piece of seaweed was cut off from the plant. The sediment was collected with the aid of a small shovel. All 62 samples (10 from bottom sediments and 52 


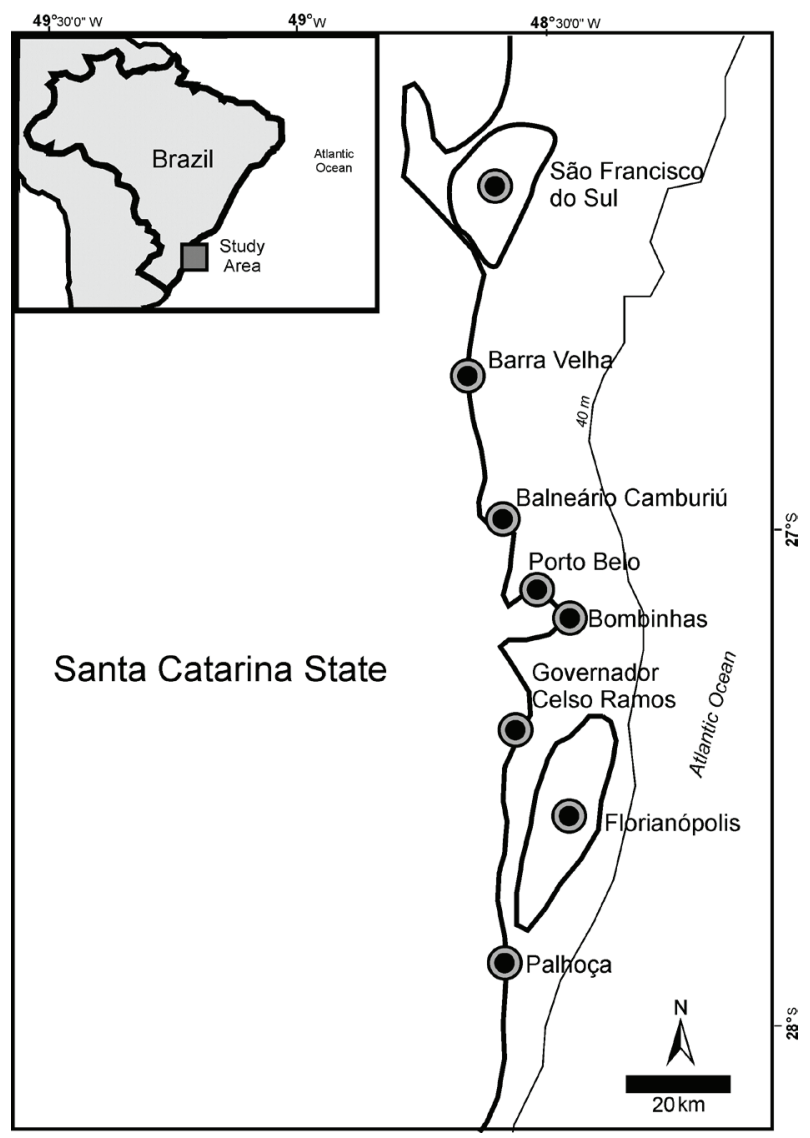

Fig. 1. Location map of the study area, state of Santa Catarina, Brazil.

phytal) were fixed in $8 \%$ formaldehyde in the field. In the laboratory, the algal material was washed through a 0.250 $\mathrm{mm}$ mesh and all specimens (living and dead) were picked under stereomicroscope. Living specimens were stored in vials containing alcohol $70 \%$, and empty carapaces and isolated valves were glued in micropaleontological slides.

The material herein examined is held in the collections of the 'Museu de Paleontologia', Universidade Federal do Rio Grande do Sul (UFRGS), Section of Ostracoda. The figured specimens are identified by the prefix MP-O. All SEM photographs were taken at the 'Centro de Microscopia Eletrônica' at UFRGS. Morphological abbreviations: LV, left valve; RV, right valve; c, carapace; $\mathrm{v}$, valve; $q$, female; $\hat{\partial}$, male. Unfortunately, the paratype MP-O-2469 was lost after SEM procedures.

\section{TAXONOMY}

Hemicytheridae, Hemicytherinae, Aurilini

\section{Auricythere gen. nov.}

Type species: Auricythere sublitoralis sp. nov., by monotypy.

Diagnosis. Carapace small, somewhat ear-shaped mainly in LV lateral view. LV conspicuously larger than $\mathrm{RV}$; overlap pronounced in dorsal region and immediately above the caudal process. Surface ornamented by costae and reticulae. Ribs predominantly low, thick and somewhat truncated. Ocular tubercle well developed, crossed by a strong rib. Ventro-lateral rib not superimposed on the corresponding margin. Posterior region with vertical rib bifurcated at the top and the bottom. Accommodation groove well developed. Hinge holamphidont; LV posterior socket with a conspicuous aurila-tooth and an auxiliary anti-slip tooth at its posterior end (sensu JELLINEK, 1995). Central muscle scars with three frontal and four adductors $(1+2+1+1)$. The frontal ones sometimes not well defined; upper and middle scars frequently somewhat anastomosed. Large duplicature with anterior vestibule. Radial porecanals numerous, simple and straight. Sexual dimorphism not prominent; females a bit higher and longer.

Etimology. From Latin origin, auris $=$ outline similar a human ear.

Remarks. According to Benson (1961), the hemicytherid ostracodes invariably have one or two of the four adductor scars subdivided. However, Hazel (1967) claims that Hemicytherinae is the only subfamily of Hemicytheridae with one or more subdivided adductor scars.

Regarding to the frontal muscle scars, Hemicytherinae can be subdivided into two groups with two or three scars (BENSON, 1961; MoRKhoven, 1963; HAzel, 1967). JELLINEK (1995, tab. 2) presents a comparative table of the genera grouped into the Tribe Aurilini, highlighting that this would be the only tribe to include genera of

Tab. I. Occurrence of Auricythere sublitoralis gen. nov., sp. nov. in the study area.

\begin{tabular}{|c|c|c|c|c|c|c|}
\hline Sample & Municipality & Beach & Coordinates & Substrate & $\mathrm{N}^{\circ}$ carapaces & $\mathrm{N}^{\circ}$ valves \\
\hline$\overline{\mathrm{M} 0901 \mathrm{~N}}$ & Florianópolis & Armação & $27^{\circ} 43^{\prime} \mathrm{S} / 48^{\circ} 30^{\prime} \mathrm{W}$ & Algae & 0 & 2 \\
\hline M0904N & Florianópolis & Armação & $27^{\circ} 43^{\prime} \mathrm{S} / 48^{\circ} 30^{\prime} \mathrm{W}$ & Algae & 0 & 2 \\
\hline M0905N & Florianópolis & Ponta das Canas & $27^{\circ} 23^{\prime} \mathrm{S} / 48^{\circ} 26^{\prime} \mathrm{W}$ & Sediments & 0 & 2 \\
\hline M0910N & Florianópolis & Naufragados & $27^{\circ} 50^{\prime} \mathrm{S} / 48^{\circ} 33^{\prime} \mathrm{W}$ & Algae & 1 & 6 \\
\hline M0955N & Barra Velha & Grant & $26^{\circ} 41^{\prime} \mathrm{S} / 48^{\circ} 40^{\prime} \mathrm{W}$ & Algae & 1 & 0 \\
\hline M0941N & Porto Belo & Estaleiro & $27^{\circ} 07^{\prime} \mathrm{S} / 48^{\circ} 31^{\prime} \mathrm{W}$ & Algae & 0 & 3 \\
\hline M0942N & Porto Belo & Estaleiro & $27^{\circ} 07^{\prime} \mathrm{S} / 48^{\circ} 31^{\prime} \mathrm{W}$ & Algae & 10 & 6 \\
\hline M0943N & Porto Belo & Estaleiro & $27^{\circ} 07^{\prime} \mathrm{S} / 48^{\circ} 31^{\prime} \mathrm{W}$ & Algae & 12 & 14 \\
\hline M0946N & Bombinhas & Tainha & $27^{\circ} 12^{\prime} \mathrm{S} / 48^{\circ} 30^{\prime} \mathrm{W}$ & Algae & 0 & 1 \\
\hline M0947N & Bombinhas & Tainha & $27^{\circ} 12^{\prime} \mathrm{S} / 48^{\circ} 30^{\prime} \mathrm{W}$ & Algae & 4 & 0 \\
\hline M0960N & Bombinhas & Sepultura & $27^{\circ} 08^{\prime} \mathrm{S} / 48^{\circ} 28^{\prime} \mathrm{W}$ & Algae & 6 & 1 \\
\hline M0961N & Bombinhas & Sepultura & $27^{\circ} 08^{\prime} \mathrm{S} / 48^{\circ} 28^{\prime} \mathrm{W}$ & Algae & 11 & 11 \\
\hline M0962N & Bombinhas & Sepultura & $27^{\circ} 08^{\prime} \mathrm{S} / 48^{\circ} 28^{\prime} \mathrm{W}$ & Sediments & 1 & 1 \\
\hline M0949N & Bombinhas & Sepultura & $27^{\circ} 08^{\prime} \mathrm{S} / 48^{\circ} 28^{\prime} \mathrm{W}$ & Algae & 2 & 0 \\
\hline \multicolumn{2}{|c|}{ Total } & & & & 48 & 49 \\
\hline
\end{tabular}


Hemicytherinae with two frontal scars.

Hazel (1967) proposes that Hemicytherinae should be subdivided into three major groups: Orionina-group, Aurila-group and Muelerina-group. However, HartmanN \& PURI (1974) erects, among others, the tribes Orioninini, Aurilini and Urocythereidini, and includes, in each of them, the same genera proposed by HAzEL (1967), respectively, with minor changes. In turn, YAJIMA (1982) follows the proposal of HAzel (1967) and inserts a fourth group (monogeneric) in Hemicytherinae, Finmarchinella Swain, 1963. Diagnostic features compared among the different tribes of Hemicytherinae, confronted to those of the new genus, indicate that Auricythere gen. nov. is best allocated in Aurilini. For more details of the diagnostic characters of this tribe see JELLINEK (1995).

Auricythere gen. nov. occurs in the study area along with species of two other aurilinid genera: Auradilus costatus (Hu, 1979) and Aurila ornellase Coimbra \& Bergue, 2003. Auradilus Jellinek, 1995 differs from Auricythere gen. nov. by well-defined diagnostic features, such as the pattern of the adductor muscle scars [1(2)+2-21] and the characteristic postero-dorsal shoulder. In turn, the highly diverse and cosmopolitan genus Aurila Pokorný, 1955 is more ear-shaped in LV lateral view and possesses a quite distinct ornamentation constituted by punctae and/ or reticulae, often concentric about mid-point; never with heavy ribs. For more details of morphological features of all Aurilini genera see JeLLINeK (1995, tab. 2), and only for a review of the diagnosis of Aurila see HARRISON et al. (2000).

\section{Auricythere sublitoralis sp. nov.}

(Figs 2-21)

Mutilus sp. 1 DiAs-Brito et al., 1988:480, Pl. 2: 45. Auradilus sp. Machado et al., 2005:240, Pl. 2: 16.

Type material. Holotype, MP-O-2467, carapace, o, length: $0.56 \mathrm{~mm}$; height: $0.33 \mathrm{~mm}$. Paratypes. MP-O2468, carapace, $\hat{\jmath}$, length: $0.54 \mathrm{~mm}$; height: $0.30 \mathrm{~mm}$; MP-O-2469, A-1 carapace, ㅇ, length: $0.52 \mathrm{~mm}$; height: $0.30 \mathrm{~mm}$; width: $0.24 \mathrm{~mm}$; MP-O-2470, carapace, $\widehat{\text { ô }}$, length: $0.53 \mathrm{~mm}$; height: $0.30 \mathrm{~mm}$; width: $0.24 \mathrm{~mm}$; MPO-2471, A-1 carapace, + , length: $0.53 \mathrm{~mm}$; height: 0.31 $\mathrm{mm}$; MP-O-2472, carapace, $\widehat{0}$, length: $0.53 \mathrm{~mm}$; height: $0.30 \mathrm{~mm}$; MP-O-2473, A-1 carapace, ${ }^{\lambda}$, length: $0.52 \mathrm{~mm}$; height: $0.28 \mathrm{~mm}$.

Etymology. From Latin origin, sublitoralis $=$ situated near the seashore, because of its first record being restricted to very shallow coastal waters.

Type locality. Holotype: sample M0943N, Porto Belo town, Estaleiro beach, $27^{\circ} 07^{\prime} \mathrm{S} / 48^{\circ} 31^{\prime} \mathrm{W}$, on algae. Paratypes: MP-O-2468, sample M0941N; MP-O-2469 and MP-O-2473, sample M0961N; MP-O-2470, sample M0942N; MP-O-2471N, sample M0947N; MP-O-2472, sample M0943N. For more details, see Tab. I.

Occurrence. See Tab. I.
Description. Carapace small, thick-shelled, somewhat ear-shaped mainly in LV lateral view. Maximum height at anterior cardinal angle. In dorsal view, compressed and with subparallel sides. Maximum width in the posterior region, poorly defined. LV conspicuously larger than $\mathrm{RV}$, the margin of which overlaps it in dorsal region and immediately above the caudal process. In lateral view, anterior margin rounded, gently concave immediately in front of the anterior cardinal angle in RV. Posterior margin with discrete caudal process, more developed in RV. Dorsal margin slightly convex, sloping posteriorly, obscured by the ornamentation in LV. Ventral margin sinuous, with evident oral concavity more developed in RV. Surface ornamented by numerous ribs intercalated by depressed and reticulate areas. Ribs predominantly low, thick and somewhat truncated. Posterior region with a vertical rib subparallel to the correspondent margin, bifurcated at the top and the bottom: at the top, a short branch runs forwards and upwards while the second one reaches the posterior cardinal angle; at the base, a longer and sinuous branch runs forwards and downwards while the shorter and more rectilinear branch runs downward, turning forward before reaching the ventral margin. Eye tubercle conspicuous, crossed by a strong rib, more robust in its anterior branch that ends at about half height.Ventro-lateral rib delicate, not overlapping the corresponding margin. Six to seven well-developed reticulae adjacent to the anterior margin. Normal pore-canals sieve-type, scattered on the costae and muri. Internal view. Accommodation groove well developed in LV. Hinge holamphidont. LV posterior socket with a conspicuous aurila-tooth and an auxiliary small anti-slip tooth at its posterior end (sensu JELLINEK, 1995). Large duplicature with a conspicuous selvage nearest to the external margin anteriorly. Anterior vestibule narrow and elongated. Radial pore-canals numerous, simple and straight, more abundant anteriorly. Central muscle scars with three frontal and four adductors $(1+2+1+1)$, as follows: dorsal rounded, dorsomedian subdivided, dorsoventral sinuous and elongated, and ventral subelliptical. The frontal ones sometimes not well defined; upper and middle scars frequently somewhat anastomosed. Sexual dimorphism not prominent. Males with a little more developed caudal process and a less arched dorsal margin.

Remarks. DiAs-Brito et al. (1988) and MACHADO et al. (2005) identified erroneously specimens of Auricythere sublitoralis sp. nov. as Mutilus sp. 1 and Auradilus sp., respectively. However, BonaduCE et al. (1987) considered Mutilus Neviani, 1928 as an extinct genus whose occurrences are restricted to the Mediterranean Neogene and Quaternary. In respect to the ornamentation, Mutilus bears a typical butterfly-shape in the central area of the valves, present in all its species. Besides, this aurilinid fossil genus possesses a well-defined frame-rib, not developed in A. sublitoralis sp. nov. On the other hand, Auradilus features outline, ornamentation and central muscle scarsvery different of the new ostracode herein described, as already discussed above. 

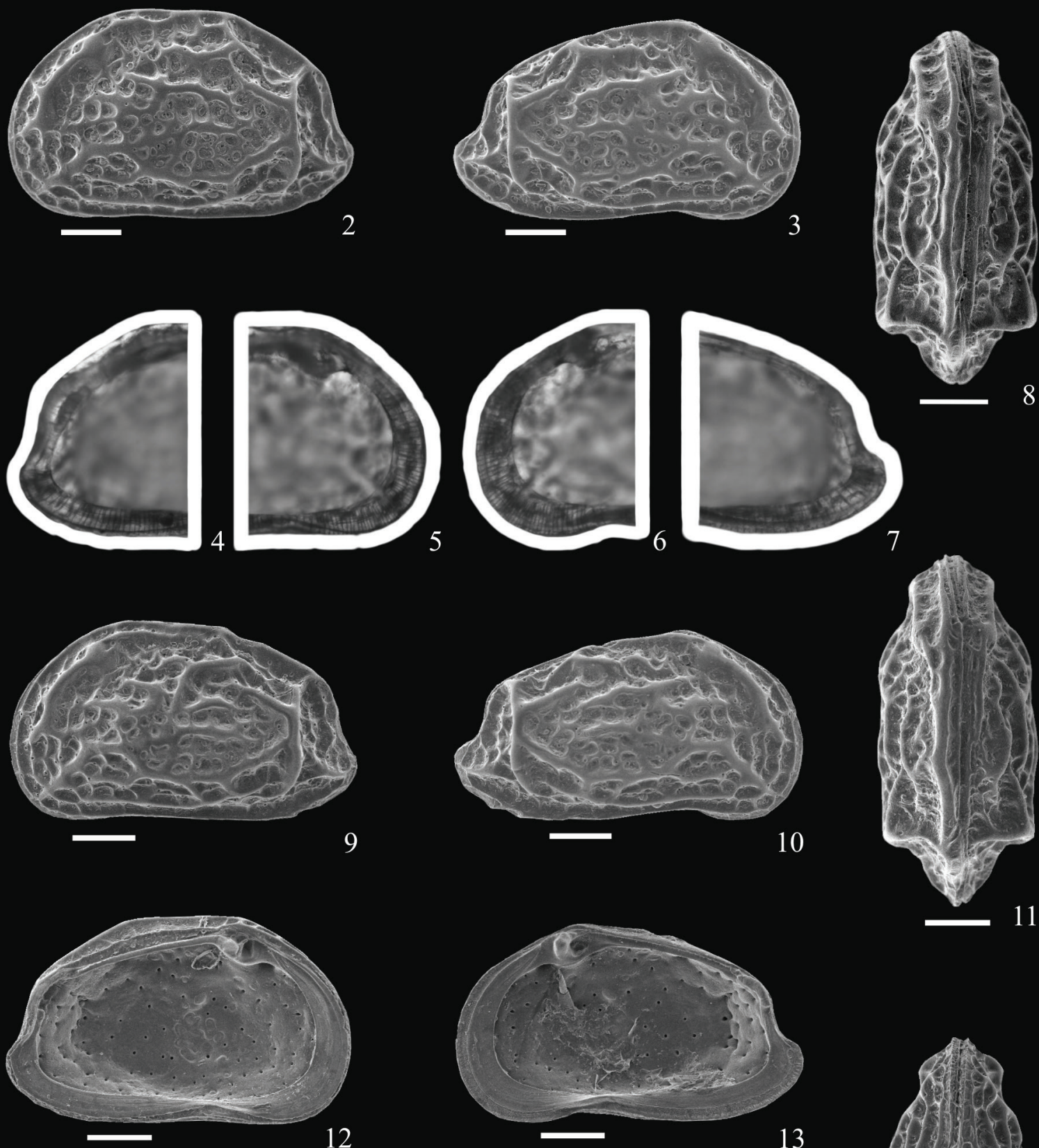

12

13
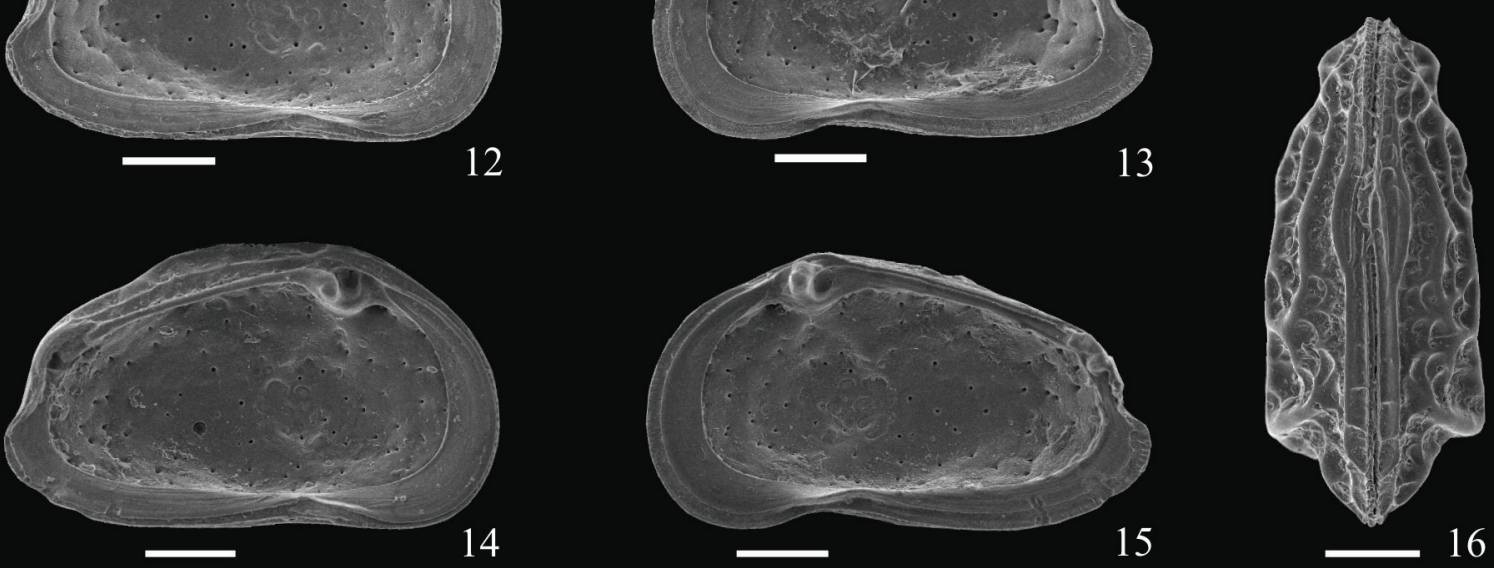

Figs 2-16. Auricythere sublitoralis gen. nov., sp. nov.: 2, MP-O-2467, LV, ๑; 3, MP-O-2467, RV,, ; 4, MP-O-2467, LV, , , posterior marginal porecanals, not in scale; 5, MP-O-2467, LV,, , anterior marginal pore-canals, not in scale; 6, MP-O-2467, RV, + , anterior marginal pore-canals, not in

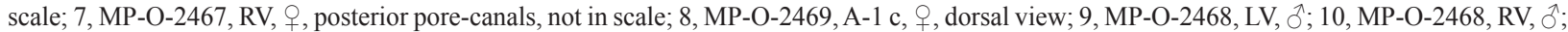
11, MP-O-2470, c, $\widehat{\jmath}$, dorsal view; 12, MP-O-2471, LV, o , internal view; 13, MP-O-2471, A-1 RV,, , internal view; 14, MP-O-2472, LV, $\widehat{\jmath}$, internal

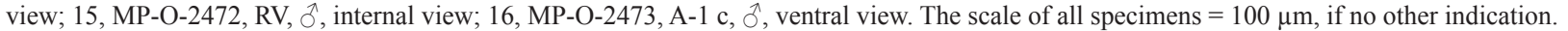




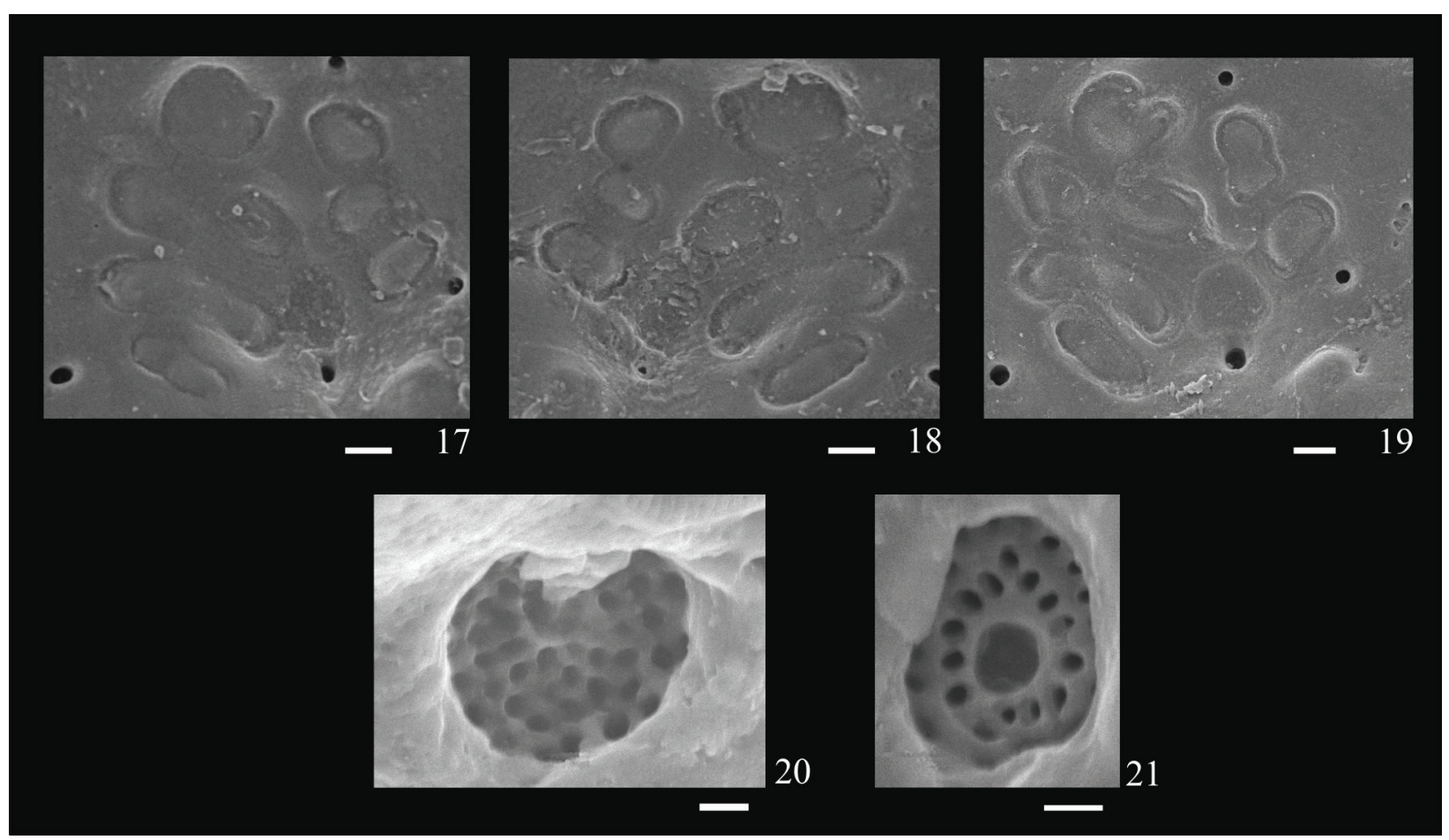

Figs 17-21. Auricythere sublitoralis gen. nov., sp. nov.: 17, MP-O-2472, LV, §, central muscle scars; 18, MP-O-2472, RV, §, central muscle scars;

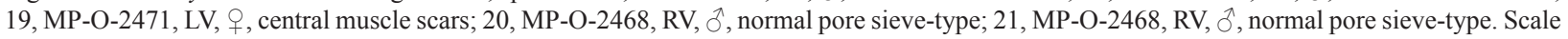
bars: $17-19=10 \mu \mathrm{m} ; 20,21=1 \mu \mathrm{m}$.

\section{DISCUSSION AND CONCLUSIONS}

In the Sepetiba Bay, Dias-Brito et al. (1988) recorded living and dead Mutilus sp. 1 (= Auricythere sublitoralis sp. nov.) in the biofacies 9 (muddy sand, 4-14 $\mathrm{m}$ water depth) and 10 (sand, 5-7 $\mathrm{m}$ water depth), regions where the temperature ranges from $23^{\circ} \mathrm{C}$ to $24^{\circ} \mathrm{C}$. These two biofacies occur in stable areas, where salinity variations are practically nonexistent.

Empty shells and isolated valves of Auricythere sublitoralis sp. nov., erroneously identified as Auradilus sp., were recorded only in three samples (out of 43) by MACHADO et al. (2005). The samples consisted of sand and were collected from the inner shelf $(43.5$ to $57 \mathrm{~m}$ water depth) off Cabo Frio town (state of Rio de Janeiro). According to Weber (1994) and Stevenson et al. (1998), the most important oceanographic feature of this area is the presence of a strong intermittent upwelling, more common in spring and summer, because coastal waters have an annual average temperature around $18^{\circ} \mathrm{C}$. This area is near the south boundary of the Transitional Assemblage of CoImBra \& OrNellas (1989) and Coimbra et al. (1995) established between $15^{\circ} \mathrm{S}$ and $23^{\circ} \mathrm{S}$ of latitude. It is likely that $A$. sublitoralis sp. nov. occurs a little more north into this Transitional Assemblage.

The meaning of this upwelling in the distribution and abundance of this species is a matter of an ongoing project.
Auricythere sublitoralis sp. nov. was recorded along rocky beaches of four municipalities (Tab. I). This species occurs in three major algal groups, as follows: (i) green algae, which occurs mostly in clusters of different species, as already verified by PUPO et al. (2011); (ii) brown algae of the genus Sargassum, also forming groups of different species, which also agrees with the observations of PuPO et al. (2011); and (iii) red algae, represented by fewer species. The ecological significance of the distribution of this new taxon is an ongoing project.

Previous analysis of 500 samples collected both by Phillips and van Veen grabs during a series of cruises throughout the Brazilian continental shelf between Rio de Janeiro (lat. $21^{\circ} \mathrm{S} /$ long. $40^{\circ} \mathrm{W}$ ) and Rio Grande do Sul states (lat. $35^{\circ} \mathrm{S} /$ long. $54^{\circ} \mathrm{W}$ ), and did not record the presence of this new taxon. The study of these samples is part of a long-term project whose goal is to describe the Ostracoda living on the southern Brazilian continental shelf (see RAmos et al., 2004, 2009, 2012 for further details).

Therefore, this new taxon is an ostracode typical of euhaline and temperate very shallow waters, occurring mainly on phytal substrates. As it is the first record of this new genus and species, the complete geographical distribution of Auricythere sublitoralis sp. nov. is still unkown.

Acknowledgements. The authors are in debt to Luiz Zonta for his help in the fieldwork, and to Dr. Cristianini Trescastro Bergue (UNISINOS) for very profitable taxonomical discussions. The first 
author acknowledge Dr. Cláudia Pinto Machado (UCS) for early discussions on Ostracoda morphology and taxonomy. A. L. M. M. and J. C. C. thank the "Conselho Nacional de Desenvolvimento Científico e Tecnológico" (CNPq) for a scholarship and for the financial support (proc. 304453/2013-7), respectively. This paper was significantly improved with the suggestions of anonymous referees and of the associated editor.

\section{REFERENCES}

Benson, R. H.; Berdan, J. M.; Bold, W. A.; Hanai, T.; Hessland, I.; Howe, H. V.; Kensling, R. V.; Levinson, S. A.; Reyment, R. A.; Moore, R. C.; Scott, H. W.; Shaver, R. H.; Sohn, I. G.; Stover, L. E.; Swain, F. M.; Sylvester-Bradley, P. C. \& Wainwright, J. 1961. Systematic descriptions. In: Moore, R. \& Pitrat, C. W. eds. Treatise on Invertebrate Paleontology, Pt. Q. Arthropoda 3, Crustacea, Ostracoda. Lawrence, Geological Society of America and University of Kansas Press p.99-421.

Bergue, C. T. \& Coimbra, J. C. 2008. Late Pleistocene and Holocene bathyal ostracodes from the Santos Basil, southeastern Brasil. Palaeontographica, Abteilung A 285:101-144.

Bonaduce, G.; Ruggieri, G. \& Russo, A. 1987. The ostracod genus Mutilus and so-called Mutilus from the Mediterranean Miocene-Pleistocene. Bollettino della Società Paleontologica Italiana 26:251-268.

BRADY, G. 1880. Report on the Ostracoda dredged by H. M. S. Challenger during the years 1873-76. Report of Scientific Results of the Voyage of H. M. S. Challenger - Zoology 1:1-184.

Coimbra, J. C. \& Bergue, C. T. 2003. A new recent marine Ostracoda species (Hemicytheridae) from Brazil. Iheringia, Série Zoologia 93:243-247.

2011. Ostracoda. In: Amaral, A. C. Z \& Nallin, S. A. H. eds. Biodiversidade e ecossistemas bentônicos marinhos do Litoral Norte de São Paulo, Sudeste do Brasil. Campinas, UNICAMP/ IB. p. 203-212.

Coimbra, J. C.; Carreño, A. L.; Geraque, E. A. \& Echler, B. B. 2007. Ostracodes (Crustacea) from Cananéia-Iguape estuarine/lagoon system and geographical distribution of the mixohaline assemblages in southern and southeastern Brazil. Iheringia, Série Zoologia 97:273-279.

Coimbra, J. C. \& Ornellas, L. P. 1989. Distribution and ecology of subRecent Orionininae (Ostracoda) in the Brazilian continental shelf. Revista Brasileira de Geociências 19:177-186.

Coimbra, J. C.; Pinto I. D.; Würdig N. L. \& Carmo, D. A. 1999. Zoogeography of Holocene Podocopina (Ostracoda) from the Brazilian equatorial margin. Marine Micropaleontology 37:365-379.

Coimbra, J. C.; Ramos, M. I. F. \& Sanguinetti, Y. T. 1992. Sub-Recent ostracodes of the Tamandaré Bay, northeastern Brazil: a preliminary report on biofacies. Pesquisas 19:94-105.

Coimbra, J. C.; Sanguinetti, Y. T. \& Bittencourt-Calcagno, V. M. 1995. Taxonomy and distribution patterns of Recent species of Callistocythere Ruggieri, 1953 (Ostracoda) from the Brazilian continental shelf. Revista Española de Micropaleontología 27:117136.

Coutinho, P. N. 2000. Oceanografia Geológica. In: Coutinho, P. N. ed. Levantamento do Estado da Arte da Pesquisa dos Recursos Vivos Marinhos do Brasil. Brasília, Ministério do Meio Ambiente dos Recursos Hídricos e da Amazônia Legal, Secretaria de Coordenação dos Assuntos do Meio Ambiente. (Programa REVIZEE). 75 p.

DiAs-Brito, D.; MourA, L. A. \& WÜRDIG, N. 1988. Re1ationships between ecological models based on Ostracodes and Foraminifers from Sepetiba Bay (Rio de Janeiro, Brazil). In: Hanai, T.; Ikeya, N. \& IsHIZAI, K. eds. Developments in Paleontology and Stratigraphy. v.11. Amsterdam, Elsevier. p. 467-484.

Harrison, D.; Maybury, C. \& Whatley, R. C. 2000. The ostracod genus Aurila from the Pliocene of north west France. Revista Española de Micropaleontología 32:21-60.
Hartmann, G. 1955. Neue marine Ostracoden der Familie Cypridae und der Subfamilie Cytherideinae der Familie Cytheridaeaus Brasilien. Zoologischer Anzeiger 154:109-127.

1956: Weitere neue marine Ostracodenaus Brasilien. In: TітSСНАK, E. \& Koерске, H. W. eds. Beitrage zur Neotropischen Fauna 1:19-62.

Hartmann, G. \& Puri, H. S. 1974. Summary of Neontological and Paleontological Classification of Ostracoda. Mitteilungausdem Hamburgischen Zoologisches Museum und Institut 70:7-73.

Hesp, P. A.; Giannini, P. C. F.; Martinho, C. T.; Da Silva, G. M. \& Neto, N. E. A. 2009. The Holocene Barrier Systems of the Santa Catarina Coast, Southern Brazil. In: Dillenburg, S. R. \& Hesp, P. A. eds. Geology and Geomorphology of Holocene Coastal Barriers of Brazil. New York, Springer. p.94-133.

Hazel, J. E. 1967. Classification and Distribution of the Recent Hemicytheridae and Trachyleberididae (Ostracoda) off Northeastern North America. Journal of Paleontology 41:1284-1285.

Jelliner, T. 1995. The Plio-Pleistocene genus Mutilus Neviani 1955 (Ostracoda) and some of its so-called Recent descendants. Senckenbergiana Lethaea 75:163-191.

Machado, C. P.; Coimbra, J. C. \& CArreño, A. L. 2005. The ecological and zoogeographical significance of the sub-Recent Ostracoda off Cabo Frio, Rio de Janeiro State, Brazil. Marine Micropaleontology 55:235-253.

Morkhoven, F. P. C. M. 1963. Post-Palaeozoic Ostracoda: their morphology, taxonomy, and economic use. Vol. 2, Generic descriptions. Amsterdam, London, New York, Elsevier. 478p.

ORnellas, L. P. 1974. Minicythereheinii Ornellas, gen. et sp. nov., from southern Brazil, and a characteristic ostracode association of brackish water environment. Anais da Academia Brasileira de Ciências 46:469-496.

Pereira, M. D.; Schettini, C. A. F. \& Omachi, C. Y. 2009. Caracterização de Feições Oceanográficas na Plataforma de Santa Catarina através de Imagens Orbitais. Revista Brasileira de Geofísica 27:81-93.

Pinto, I. D.; Ornellas, L. P.; Purper, I.; Kotzian, S. C. B. \& SAnguinetti, Y. T. 1978. Recent ostracodes along $7408 \mathrm{~km}$ of the Brazilian coast ( $33^{\circ} 45^{\prime} \mathrm{S}$ to $\left.04^{\circ} 25^{\prime} \mathrm{N}\right)$. Pesquisas 9:109-120.

Pupo, D.; Ouriques, L. C.; Funi, M. T.; Guimarães, S. M. P. B. \& Yokoya, N. S. 2011. Marine benthic algae from Santa Catarina State, Southern Brasil. Boletim do Instituto de Botânica 20:1-112.

Ramos, M. I. F. 1996. Taxonomy and zoogeography the ostracod genera Nanocoquimba and Cornucoquimba Ohmert, 1968 from Recent sediments on the Brazilian continental shelf. Revista Española de Micropalentología 28:105-128.

Ramos, M. I. F.; Coimbra, J. C. \& Whatley, R., 2004. Sub-Recent Marine Ostracoda (Pontocyprididae and Baiirdiidae) from the Southern Brazilian Continental Shelf. Revista Brasileira de Paleontologia 7:311-318.

2009. The family Thaerocytheridae Hazel, 1967 Ostracoda from the southern Brazilian continental shelf. Ameghiniana 46:285-294.

Ramos, M. I. F.; Coimbra, J. C.; Whatley, R. C. \& Bergue, C. T. 2012. Recent ostracods (Family Trachyleberididae) from the southern Brazilian continental shelf. Ameghiniana 49:3-16.

Stevenson, M. R.; Dias-Brito, D.; Stech, J. L. \& Kampel, M. 1998. How do cold-water biota arrive in a tropical bay near Rio de Janeiro, Brazil. Continetal Shelf Research 18:1595-1612.

Tessler, M. G. \& Goya, S. C. 2005. Processos Costeiros Condicionantes do Litoral Brasileiro. Revista do Departamento de Geografia 17:11-23.

Yajima, M. 1982. Late Pleistocene Ostracoda from the Boso Peninsula, Central Japan. Bulletin of the University Museum of Tokyo 20:141227.

Weber, R. R. 1994. Diagnóstico ambiental oceânico e costeiro das regiões sul e sudeste do Brasil. Oceanografia Química 3:254-263.

Received 20 June 2014. Accepted 22 September 2014. ISSN 0073-4721

Article available at: www.scielo.br/isz 